\title{
Pengembangan E-Sudent Worksheets (E-SW) Berbasis Literasi Sains Dalam Pembelajaran IPA Muatan Gaya Untuk Siswa Kelas IV Sekolah Dasar
}

\author{
Anisa Asnawati ${ }^{1}$, Sutrisno ${ }^{2}$, Imaningtyas ${ }^{3}$ \\ anisaasnaa05@gmail.com ${ }^{1}, \underline{\text { sutrisno@unj.ac.id }}^{2}$, imngtyas@uni.ac.id $^{3}$ \\ Pendidikan Guru Sekolah Dasar, Universitas Negeri Jakarta1,2,3
}

\begin{abstract}
This investigation means to deliver e-student worksheets based on Science Literacy with the content of force for the fourth grade students of primary school. This exploration is a type of research and development with the ADDIE development model consisting of three stages including analysis, design, and development. The assessment isinvolving material experts, media, linguists, elementary school teachers and students. The data was obtained by observations, interviews and questionnaires. Literacy-based e-student worksheets assessment is in accordance with the right aspects, the right aspects, the right aspects, and the right literacy aspects. The aftereffect of this examination indicate that the e-student worksheets according to Science Literacy is very suitable to be used for fourth grade elementary school students. This is proven based on the assessment by material experts of $96 \%$, linguists $94 \%$, media experts $87 \%$, elementary school teachers get an average rating of $97 \%$, one to one $93 \%$, small group $86 \%$, field test $84 \%$ if described including very good category. The implication of implementing e-student worksheet based on Science Literacy can create active, independent and meaningful learning for students, teachers can add new sources of insight, and PGSD students get an idea to conduct similar research.
\end{abstract}

Keywords: E-Students Worksheet, Scientific Literacy, Force

\begin{abstract}
Abstrak
Penelitian ini menghasilkan e-student worksheet berbasis Lietrasi Sains muatan gaya dan macamnya kelas IV SD. Penelitian ini merupakan jenis penelitian pengembanganResearch and Developmentmodel ADDIEdengan modifikasi hanya 3 langkah yaitu analisis, desain dan pengembangan. Penilaian dilakukan dengan melibatkan pakar materi, media, bahasa, guru SD serta peserta didik. Adapun data yang diperoleh dikumpulkan melalui observasi, wawancara dan kuesioner. Penilaian e-student worksheetsmeliputi aspek kelayakanmateri,penyajian,kebahasaan, kegrafikan dan aspek komponen literasi sains. Hasil penelitian ini mebuktikkan bahwa e-student worksheets berbasis Literasi Sains sangat layak dipakai peserta didik Kelas IV SD. Hal ini dibuktikkan berdasarkan penilaian oleh ahli materi sebesar $96 \%$, ahli bahasa $94 \%$, ahli media $87 \%$. Adapun penilaian berdasarkan respon pengguna yaitu guru oleh wali kelas IVA sebesar $98 \%$ dan wali kelas IVB sebesar $98 \%$ memperoleh presentase rata-rata kelayakan produk sebesar $97 \%$. Sedangkan uji coba respon pengguna oleh peserta didik yaitu uji coba one to one(satu-satu) $93 \%$, uji coba small group(kelompok kecil) $86 \%$, uji coba field test(uji lapangan) $84 \%$ apabila dideskripsikan termasuk kategori sangat baik. Implikasi dari penerapan e-student worksheets berbasis Literasi Sains dapat menciptakan pembelajaran yang aktif, mandiri serta bermakna untuk peserta didik, guru dapat menambah sumber wawasan baru, dan mahasiswa PGSD mendapat gambaran untuk melakukan penelitian sejenis.
\end{abstract}

Kata Kunci:E-Student Worksheets, Literasi Sains, Gaya dan Macamnya

\section{PENDAHULUAN}

Dalam rilis amandemen program pendidikan tahun 2013, terdapat 4 fokus signifikan harus diimplementasikan, khususnya penguatan pendidikan karakter (PPK), kemahiran, kemampuan abad 21 yang menggabungkan korespondensi, usaha bersama, penalaran dasar dan berpikir kritis, inventif dan pengembangan (4C), dan permintaan kemampuan penalaran yang lebih tinggi (HOTS). Senada dengan hal tersebut maka dari itu dalam pembelajaran sains penting untuk membuat kemajuan menuju penemuan ilmu pengetahuan yang dapat bekerja dengan peserta didik untuk berpikir secara 


\section{Efektor, Volume 8 Issue 2, 2021, Pages 98-109}

Anisa Asnawati, Sutrisno, Imaningtyas

fundamental, memiliki daya pikir yang tinggi, dan berpikir kreatif dalam menangani isu-isu alam yang terjadi. Sehingga diperlukan bahan ajar yang aplikatif untuk kepentingan peserta didik.

Bahan ajar adalah asset pembelajaran hingga sampai saat ini memiliki tugas yang signifikan untuk membantu siklus belajar (Ahmad dan Lestari, 2010:183). Karena bahan ajar dapat dijadikan sebagai sumber belajar peserta didik dalam meninjau kembali topik yang telah diperoleh selama di sekolah secara mandiri juga dapat dipakai guru dalam memandu dan menampilkan kompetensinya. Bahan ajar yang baik adalah materi instruksi yang mengandung segmen pendidikan logis dengan cara yang layak (komponen literasi sains seimbang). Penggunaan bahan ajar secara optimal menjadi bagian strategis penerapan kurikulum 2013. Namun, berdasarkan observasi yang dilakukan peneliti di SDN Lenteng Agung 03 pada kenyataannya belum optimalnya penggunaan bahan ajar di dalam kelas. Hal ini disebabkan oleh sebagian besar guru hanya berminat menggunakan buku teks dan buku tematik satu-satunya patokan dalam mengajar.Padahal terdapat beranekaragam bahan ajar selain buku teks bacaan yang sebenarnya sangat layak dalam memperluas pemahaman peserta didik.

Kualitas penyajian materi yang buruk dengan pembelajarantradisional menyebabkan minimnya kemampuan literasi sains peserta didik di Indonesia sehingga minat belajar IPA pun rendah dan berakibat rendahnya perolehan prestasi belajar peserta didik. Terlebih di era ini pergeseran tenaga pengajaran yang pada awalnya merupakan asset pembelajaran tersendiri, kini menjadi fasilitator peserta didik, sehingga hadirnya materi atau buku panduan yang dapat menghubungkan masalah keterbatasan daya serap peserta didik sertadependensi kapasitas guru untuk mendidik. Dan pengukuran pembelajaran didalam kelas.

Eksitensi bahan ajar berfungsi menginterpretasikan yang relevan pada kualitas individu peserta didik, meliputi masalah rendahnya kesadaran diri peserta didik, sehingga muatan yang tidak bisa dipahami dapat diteliti dan dipelajari secara berulangvia materi ajar (Ahmad dan Lestari, 2010:183). Senada dengan hal tersebut maka dibutuhkanlah berbagai variasi bahan ajar selain buku teks dan buku tematik untuk mencapai kebutuhan dan tujuan kurikulum yang berlaku. Bahan ajar memiliki jenis yang berbeda-beda, ada yang tercetak maupun tidak tercetak (Yuberti, 2014:191). Bahan ajar elektronik adalahperagadimanasubstansinya terkandung pada suatu rancangan elektronik, yang dapat berupa, suara, media umum, atau media campuran intuitif. Bahan ajar yang paling banyak dipakai saat ini seperti buku teks dan buku tematik. Bentuk bahan ajar ini, diperuntukkan untuk dibaca peserta didik.

Tetapi, eksitensi bahan ajar ini acap kalikurangmemikat afinitas peserta didik dalam mengeksplorasi, membaca fakta yang ada didalamnya. Fenomenal ini disebabkan bahan ajar ditampilkan secaratidak hati-hati, ketiadaan data, dan pengayaan seperti visual ilustrasi yang jelek, atau bisa juga karena sumber materi pertunjukan yang diperkenalkan terlalu kacau, merepotkan, dan berulang-ulang (Ermaniatu dan Taufik, 2017:286). Berdasarkan temuan penelitian oleh Windyariani dkk, meneliti bahwa, kebiasaan pembelajaran IPA di Sekolah Dasar pada umumnya lebih diatur pada pertukaran informasi dan setting yang tidak berkaitan dengan kehidupan sehari-hari. (Windyariani, dkk, 2016:20). Hal tersebut menunjukkan bahwa selama ini, bahan ajar yang digunakan hanya berfokus pada kapasitas pengetahuan peserta didik tanpa berfokus pada bagian-bagian pemikiran dan penilaian penggunaan ide-ide sains yang diimplemntasikan kedalam kehidupan sehari-hari.

Kondisi ini tentunya dapat menyebabkan rendahnya mutu lulusan pendidikan karena belum efektinya teknik pembelajaran. Terlebih dewasa ini banyak sekali informasi yang memuat ketidaklayakan bacaan mata pelajara yang digunakan peserta didik dalam ukuran pengajaran dan pembelajaran di sekolah yang kurang efektif, mislanya konten yang tidak relevan dengan kondisi sekolah, iklim belajar, kesalahan dalam materi, overlaving dan stagnasi materi. (Juwita, dkk, 2017:64). Dapat disimpulkan bahwa faktanya relevansi antara isi dan kebutuhan pembelajaran kurang terakomodasi dan kurang selaras dengan kebutuhan pendidikan. Hal ini ditemukan dalam penelitian yang dilakukan oleh Purnomo dan Wilujeng dalam judul"Pengembangan Bahan Ajar dan Instrumen Penilaian IPA Tema Indahnya Negeriku Penyempurnaan Buku Guru dan Buku Siswa Kurikulum 2013" bahwa pada setiap keterampilanbelajar masih terdapat kesalahan pada kemampuan pembelajaran 


\section{Efektor, Volume 8 Issue 2, 2021, Pages 98-109}

Anisa Asnawati, Sutrisno, Imaningtyas

dalam KI, KD dan Indikator pembelajaran dalam kemampuan belajar di buku instruktur serta peserta didik program pendidikan 2013, khususnya pada kompetensi pembelajaran IPA paling banyak ditemukan ketidakrelevan kompetesi pembelajaran yang disajikan dengan KI, KD dan Indikator Pembelajaran yang ada dalam buku guru danpeserta didik Kurikulum 2013 (Purnomo dan Wilujeng, 2016:69). Buku teks pun dapat menyebabkan miskonsepsi materi. Hal ini dibuktikkandengan temuan Laksana (2016) berjudul "Miskonsepsi Dalam Materi IPA Sekolah Dasar"bahwa hasil penyelidikan muatan ajar seperti buku teks membuktikkan sebagian persepsi sainsmengandung konsep yang dapat menyebabkan miskonsepsi diantaranya yaitu konsep benda diam mengalami gaya sebesar $59,44 \%$ dan persepsi gaya garavitasi dalam permukaan bulan sebesar 78,1\% (Laksana, 2016:173). Oleh karena itu, peserta didik dan guru membutuhkanaltenatif bahan ajar lain sebagai pijakan belajar sains, khusunya sains fisika yang memperjelas hubungan antara ide-ide sains fisik dan kehidupan sehari-hari yang teratur.

Untuk membuktikan kajian yang telah peneliti dapatkan berdasarkan studi pustaka kajian jurnal selanjutnya peneliti melakukan studi lapangan melalui wawancara dan penyebaran kuesioner. Menurut analisis kebutuhan oleh peneliti, dari hasil riset pertama melalui wawancara guru kelas IV didapatkan data bahwabahan ajar yang dipakai dalam pembelajaran IPA adalah $66,7 \%$ buku tematik dan $33,3 \%$ buku teks dimana buku teks dan buku tematik terkadang menyebabkan miskonsepsi materi, sulit dimengerti oleh guru dan peserta didik, dan juga relevansi antara isi dan kebutuhan pembelajaran terkadang kurang terakomodasi dan kurang selaras dengan kebutuhan pendidikan dimana buku yang dipakai terdapat isi yang kurang sinkron dengan keadaan lingkungan. Dan juga dalam buku guru yang diberikan terdapat beberapa bagian ketidaksesuaian antara KI, KD, serta tujuan pembelajaran. Selain itu, bahan ajar yang dipakai saat ini hanya memuat konten teori materi saja tanpa disajikan ragam informasi unik terkait materi yang bermanfaat dalam kehidupan. Hal tersebut merupakan penyebab rendahnya literasi sains. Sehingga guru dan peserta didik memerluka referensi bahan ajar lain selain buku teks dan buku tematik.

Guru setuju dengan kehadiran e-student worksheets berbasis Literasi Sains dimana diharapkan peserta didik dapat belajar terarah dan tanpa dibatasi ruang dan waktu untuk mengexplore lingkungan Sains sekitar kita, mendorong peserta didik untuk berliterasi sehingga mampu mendukung kemampuan di abad-21, dan membantu guru memenuhi tujuan kurikulum. Adapun berdasarkan penyebaran kuesioner kepada peserta didik dapat peneliti simpulkan bahwasanya peserta didik 90,3\% membutuhkan bahan ajar yang lebih kreatif dan menarik selain buku teks dan buku tematik karena bahan ajar tersebut $71 \%$ kurang menarik, terkadang sulit untuk memahami materi dan terkadang menimbulkan kebosanan. Peserta didik membutuhkan bahan ajar dimana bahan ajar tersebut tak hanya seputar materi, penugasan-penugasan dan menyajikan ilustrasi gambar yag menarik. Berdasarkan hasil studi literature yang ditempuh oleh peneliti diperoleh data bahwa e-student worksheets berbasis literasi sains mampu memajukan indeks belajar peserta didik, kapabilitas berpikir kritis, meningkatkan motivasi sains dapat meningkatkan motivasi sains serta e-student worksheets berbasis literasi sains juga dinyatakan 93,39\% valid, 97,65\% praktis dan efektif sehingga layak digunakan untuk mengakomodasi kegiatan pembelajaran.Dalam pemilihan materi dilakukan berdasarkan riset kajian teoritik literasi sains dimana tak semua topik dapat diangkat pada basis literasi sains hal tersebut dikemukakan dalam dimensi literasi sains menurut PISA.

Menurut Puspita dan Dewi (2021) pemanfaatan e-student worksheets dalam pembelajaran mempengaruhi latihan belajar peserta didik menjadi lebih menyenangkan, seperti halnya memberikan kebebasan kepada peserta didik untuk berlatih dan membangkitkan peserta didik dalam pembelajaran (Puspita dan Dewi, 2021:89). E-student worksheet dapat dioperasikan secara mudah melalui gadget. Data pada e-student worksheetdilengkapi dengan link, gambar dan video yang dapat meningkatkan pemahaman peserta didik terkait materi sehingga tidak menimbulkan miskonsepsi materi. Menurut Reny Kristyowati (2018) e-student worksheets memiliki empat matlamat, yaitu: sebagai bahan ajar yang membantu peserta didik untuk berinteraksi dan mengembangkankapabilitasterkait materi yang 


\section{Efektor, Volume 8 Issue 2, 2021, Pages 98-109}

Anisa Asnawati, Sutrisno, Imaningtyas

dipelajari, melatih kemandirian belajar peserta didik dan membantu pendidik dalam pengajaran (Kristyowati, 2018:34). Berdasarkan hasil studi literatur yang ditempuh oleh peneliti terdapat penelitian pengembangan yang berhasil mengembangkan e-student worksheets berbasis literasi sains. Berdasarkan uji coba yang dilakukan Zahroh (2021) dalam penelitian yang berjudul "Pengembangan eLKPD Berbasis Literasi Sains Untuk Melatihkan Keterampilan Berpikir Kritis Peserta Didik Pada Materi Pertumbuhan dan Perkembangan" bahwa e-LKPD berbasis literasi sains dapat memajukan indeks belajar peserta didik, keterampilan berpikir kritis, meningkatkan motivasi sains serta lembar kerja peserta didik electronic literasi sains materi gaya dan macamnya juga dinyatakan 93,39\% valid, 97,65\% praktis, dan efektif sehingga layak digunakan untuk mengakomodasi kegiatan pembelajaran (Zahroh, 2021:615).

Berdasarkan permasalahan yang didapat melalui studi pustaka dan studi lapangan melalui analisis kebutuhan. Dengan demikian, dibutuhkan variasi bahan ajar lain dimana bahan ajar tersebut tidak hanya memuat konten teori materi saja namun membutuhkan bahan ajar yang dilengkapi dengan pengetahuan terkait materi yang dapat bermanfaat dalam kehidupan sehari-hari sehingga dibutuhkan variasi bahan ajar selain buku teks, buku tematik agar tidak menimbulkan miskonsepsi materi.

Atas dasar permasalahan tersebut, peneliti memutuskan akan mengembangkan e-student worksheets berbasis Literasi sains dengan memperhatikan karakteristik kelas IV SD di SDN Lenteng Agung 03. Dimana e-student worksheets yang akan peneliti kembangkan dilengkapi dengan ragam fakta unik pengetahuan yang tak hanya konsep sains saja namun memuat konsep sains,konten sains dan aplikasi sains melalui proses penemuansehingga ilmu yang di pelajari dapat diterapkan dalam kehidupan sehari-hari sehingga pembelajaran menjadi bermakna. Dan juga dalam e-student worksheet berbasis Literasi Sains ini akan disertai link-link pembelajaran dimana link tersebut mudah diakses melalui gadget maupun laptop sehingga peserta didik dapat melek digital dan sains. Selain itu, dalam estudent worksheet berbasis Literasi Sains terdapat permainan sains terkait materi serta quiz sains sehingga dapat menstimulus kerja otak anak agar pembelajaran dapat berjalan secara optimal. Basis dalam produk ini yaitu literasi sains sebagai pembeda dari bahan ajar yang sudah ada seperti bahan ajar berupa buku teks dan buku tematik. Dimana prinsip dasar literasi sains bertumpu pada pembelajaran abad ke-21 berlandaskan harmonis dalam variasi literasi yang tak hanya mencakup konsep sain saja, juga mencakup konten sains, dan aplikasi sains melaui proses penemuan berupa fakta, konsep, identifikasi pertanyaan, penyelidikan berupa praktikum untuk menafsirkan informasi secara kritis sehingga mampu memecahkan masalah dan mampu mengaplikasikan pengetahuan ilmiah yag telah dipelajari dalam kehidupan sehari-hari Hal tersebut relevan pernyataan Haristy, dkk (2013) bahwa proses pembelajaran yang mengimplementasikan literasi sains dapat meningkatkan hasil belajar dan kompetensipendidikan logika literasi sians.Sains mengangkat topik permasalahan dari kehidupan nyata sehingga peserta didik akan mengetahui secara langsung makna dan manfaat materi yang dipelajari dikaitkan dengan implementasi dikehidupan nyata.

Atas dasar permasalahn tersebut, dibuatlah pengembangane-student worksheetberbasis literasi sainsuntukmengetahui kelayakan produk lembar kerja peserta didik elektronik. Selain itu, diharapkan dapat menciptakan pembelajaran yang menarik dan mengedukasi sesuai dengan pembelajaran kreatif, inovatif dan berkarakter sains melalui "Pengembangan E-Student Worksheet (ESW) Berbasis Literasi Sains dalam Pembelajaran IPA Muatan Gaya untuk Siswa Kelas IV Sekolah Dasar."

\section{METODE PENELITIAN}

Metode investigasi initercatat kategori Research and Development.Research and Development merupakanteknik yang dipakaidalammeningkatkan dan verifikasipabrikasi yang dipakaipada invesdtigasi (Hanafi, 2017:134). Sedangkan RnDdalam ranah pendidikan adalah kategoriinvestigasidengan mewujudkan pabrikasidalam pengkajian yang dahului dengan kajian kepentingan, eskalasi pabrikasi, komentar pabrikasi, revisi, dan transmisi pabrikasi atau disebut juga 
disseminasi (Purnama, 2013:21). Metode (RnD) adalah prosedur penelitian untuk mewujudkan sebuah pabrikasi berupa bahan ajar maupun media pembelajaran melalui penelitian yang bertujuan menyelamipangkat kelayakan dan efektivitas pabrikasi sehingga dapat menghasilkan produk yang layak digunakan dalam bidang keahlian tertentu. Untuk membuat item, memerlukan model dalam kemajuan informative untuk memudahkan mewujudkan pabrikasi yang relevan dengan kepentingan dan individualitas pembelajar. Peneliti mengembangkan menggunakan model ADDIE.Model ADDIE mencakup lima tahapan, meliputi: 1) analyze, 2) design, 3) development, 4) implementation, 5) evaluate. Namun, dalam penelitian ini peneliti mengacu pada model pengembangan ADDIE dengan modifikasi hanya 3 langkah yaitu, analisis, desain, dan pengembangan. Langkah-langkah penelitian dan pengembangan yang telah dijabarkan diatas, dapat diliustrasikan sebagai berikut:

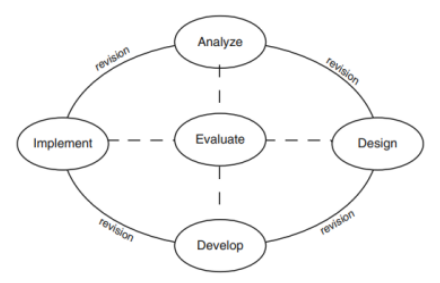

\section{Gambar 1. Pengembangan Model ADDIE Menurut Robert Maribe Branch}

Tahapan pada penelitian ini dijelaskan lebih rinci sebagai berikut:

\section{Analisis (analyze)}

Dalam fase ini, peneliti melakukan penyelidikan masalah, pemeriksaan kebutuhan, penyelidikan materi, dan merinci karakteristik peserta didik kelas IV.

\section{Desain (design)}

Dalam fase desain peneliti melakukan merumuskan tujuan, menyusun tes yang berkaitan dengan tujuan pembelajaran atau menyusun garis besar isi dengan memilih materi sesuai dengan karanteristik, topik, literasi sians, KD dan kurikulum yang berlaku dan strategi pembelajaran, menentukan alat dan sumber bahan ajar yang dibutuhkan.

\section{Pengembangan (development)}

Konsep dalam fase development adalah memvalidasi sumber-sumber belajar dan merealisasikan pabrikasisebelumdipabrikasikan, tahap pabrikasi serta fasesetelah pabrikasi. Kemudian dilakukan uji validitas produk melalui validasi expert review oleh pakar materi, bahasa sertamedia. Selanjutnya produk diuji cobakan kepada respon pengguna yaitu peserta didik melalui uji coba one to one, small group dan field test serta guru sebagai pemakai. Setelah diterapkan dan diujicobakan maka akan diperoleh kritik dan saran. Kemudian dilakukan revisi untuk memperbaiki kelayakan e-student worksheets berbasis Literasi Sains. Review ini dilakukan berdasarkan saran ahli materi, media, bahasa serta review respon pengguna.

Investigasi dilaksanakan di SDN Lenteng Aging 03 pada semester genap tahun pelajaran 2020/2021. Subjek investigas yaitu peserta didik kelas IV SD sejumlah 40 meliputi 29 peserta didik kelas IV A serta 11 peserta didik kelas IVB di SDN Lenteng Agung 03. Teknik pengumpulan data pada investigasididapatkan melalui observasi, wawancara guru dan penyebaran kuesioner kepada wali kelas IV serta peserta didik untuk mengetahui permasalahan-permasalahan yang ada. Setelah menganalisis permasalahan yang ada berdasarkan wawancara dan penyebaran kuesioner, peneliti menganalis permasalahan berdasarkan jurnal lalu menganalis bahan ajar yang simultandimanfaatkan dalam memecahkan permasalahan yang ada melalui analisis jurnal terkait bahan ajar yang layak digunakan dalam pembelajaran

IPA. Populasi yang peneliti ambil pada investigasi ini adalah peserta didikkelasIV. Peneliti memutuskan 
kelas IVdisebabkan topik atau materi yang akan peneliti pakan adalah materi gaya dan macamnya. Peneliti memilih materi gaya dan macamnya karena berdasarkan analisis jurnal terdapat materi yang menimbulkan miskonsepsi materi, selain itu materi tersebut juga dapat diangkat dalam pengembangan basis literasi sains menurut PISA dalam dimensi literasi sains. Dan materi tersebut diajarkan pada semester 2 (dua) sehingga peneliti dapat mengaplikasikan tepat saat pembelajaran tersebut sudah waktunya diajarkan. Dalam pengembangannya e-student worksheets berbasis Literasi Sains yang dikembangkan akan dievaluasi oleh peneliti sendiri melalui tahap self evaluation. Kemudian, di verifikasitigapakarmeliputi: pakarmateri, bahasan dan media. Selanjutnya e-student worksheets berbasis Literasi Sains yang telah diuji akan diuji lapangan. Pada tahapan ini e-student worksheets berbasis Literasi Sains akan diuji cobakan kepada peserta didik kelas IVB untuk uji coba one to one oleh 3(tiga) peserta didik dan small group oleh 8 (delapan) peserta didik melaluizoom dalam pelakasanaannya. Setelah itu, uji coba pelaksanaan (field test) dilaksanakan dalam kelas IVA melalui pembelajaran daring via whatsapp group yang terdiri dari 29 peserta didik.

Skala pengukuran yang dipakaipada Instrumentpenelitian ini adalah rating scale. Pada skala penelitian, para ilmuwan harus menguraikan setiap angka yang ditawarkan pada setiap jawaban dan instrument, dengan alasan bahwa setiap orang memiliki pandangan yang berbeda. Denganinipeneliti menafsirkansetiapangkasebagaiberikut:5 adalahsangatbaik; 4adalahbaik; 3adalahcukupbaik; 2 a dalah kurang baik; 1 adalah sangat kurang baik. Kemudian dikonversi menjadi statistikdeskriptif kualitatif.Untuk menghitung ditafsirkan dengan skala 1-5.

skor kriteria dihitung dengan rumus dibawah ini dan

\section{Jumlah nilai hasil pengumpulan data $\times 100 \%$}

\section{Jumlah butir soal $\times$ poin tertinggi}

Dalam menguraikandata kuantitatif menjadi data kualitatif, digunakan tumpuan sebagai berikut:

Tabel 1. Konversi Tingkat Pencapaian dengan Skala 5

\begin{tabular}{ll}
\hline Deskripsi & Skor \\
\hline Sangat Kurang Baik & $0 \%-20 \%$ \\
\hline Kurang Baik & $21 \%-40 \%$ \\
\hline Cukup Baik & $41 \%-60 \%$ \\
\hline Baik & $61 \%-80 \%$ \\
\hline Sangat Baik & $81 \%-100 \%$ \\
\hline
\end{tabular}

\section{HASIL DAN PEMBAHASAN \\ Hasil Validitas Expert Review}

Dalam validasi ahli, produk akan dinilai relevan dengan instrument dalam teori bab 2melingkupiprospek kelayakan isi atau materi, penyajian, prospek kelayakan kebahasaan, prospek kelayakan kegrafikan. Peneliti menambahkan penilaian prospek atau aspek komponen literasi sains.

Dalam uji coba expert review, yang menjadi ahli materi yaitu..Drs. A.R. Supriatna, M.Pd., ahli bahasa yaitu Rahmah Purwahida, S.Pd., M.Hum, dan ahli media yaitu Prof. Dr. M. Syarif Sumantri, M.Pd. Dibawah ini hasil rekapitulasi penilaian ahli materi: 
Efektor, Volume 8 Issue 2, 2021, Pages 98-109

Anisa Asnawati, Sutrisno, Imaningtyas

Tabel 2. Hasil Rekapitulasi Ahli Materi

\begin{tabular}{lllll}
\hline Aspek & $\begin{array}{l}\text { Nomer } \\
\text { Kuesioner }\end{array}$ & $\begin{array}{l}\text { Skor } \\
\text { Maksimum }\end{array}$ & $\begin{array}{l}\text { Skor } \\
\text { Perolehan }\end{array}$ & Presentase \\
\hline Kelayakan Isi atau Materi & $1-10$ & 50 & 48 & $96 \%$ \\
\hline Kelayakan Penyajian & $11-13$ & 15 & 15 & $100 \%$ \\
\hline Kelayakan Kebahasaan & $14-23$ & 50 & 48 & $96 \%$ \\
\hline Komponen Literasi Sains & $24-33$ & 50 & 49 & $96 \%$ \\
\hline Total & 33 & 165 & 160 & $96 \%$ \\
\hline
\end{tabular}

Berdasarkan hasil diatas, diinfersikan validasi e-student worksheetsberbasis literasi sains dalampembelajaran IPA muatan gaya dan macamnya yang sudah dinilai pakar materi dilihat dari prospek kelayakan materi didapatkan presentase sebesar $96 \%$, prospek kelayakan penyajian sebesar $100 \%$, prospek kelayakan kebahasaan sebanyak $96 \%$ dan prospek komponen literasi sains sebesar $96 \%$ sehingga didapatkan rata-rata kelayakan produk sebanyak $96 \%$ dengan kategori sangat baik. Langkah berikutnyaa e-student worksheets berbasis literasi sains pembelajaran IPA materi gaya dan macamnya ini di validasi oleh ahli bahasa. Dibawah ini hasil rekapitulasi ahli bahasa.

Tabel.3. Hasil Rekapitulasi Ahli Bahasa

\begin{tabular}{ccccc}
\hline Aspek & $\begin{array}{c}\text { Nomer } \\
\text { Kuesioner }\end{array}$ & $\begin{array}{c}\text { Skor } \\
\text { Maksimum }\end{array}$ & $\begin{array}{c}\text { Skor } \\
\text { Perolehan }\end{array}$ & Presentase \\
\hline Kelayakan Kebahasaan & $17-26$ & 50 & 47 & $94 \%$ \\
\hline Total & 10 & 50 & 47 & $94 \%$ \\
\hline
\end{tabular}

Berdasarkan tabel diatas,validasi e-student worksheets berbasis literasi sains dalam pembelajaran IPA muatan gaya dan macamnya yang telah dinilai oleh ahli bahasa dilihat dari aspek kebahasaan diperoleh presentase sebesar $94 \%$ dengan kategori sangat baik. Adapun kriteria dalam aspek kelayakan kebahasaan terdiri dari keterbacaan, relevan dengan struktur EYD dan benar (ketepatan kaidah bahasa), penalaran berbahasa disesuaikan dengan bidang kajian, bahasa disesuaikan dengan tingkat perkembangan intelektual, bahasa disesuaikan dengan tingkat perkembangan sosial emosional, keruntutan dan keterpaduan antar bab, ketepatan penggunaan istilah, pemakaian bahasa yang komunikatif, pemakaian bahasa yang mudah memahami alur materi, menggunakan struktur kalimat yang jelas untuk menyusun pertanyaan dalam e-student worksheets. Berdasarkan hasil validasi tersebut dapat diartikan bahwa produk e-student worksheets berbasis literasi sains pembelajaran materi gaya dan macamnya menurut ahli bahasa dikategorikan sangat baik dengan presentase 94\%. Langkah selanjutnya e-student worksheets berbasis literasi sains pada pembelajaran IPA materi gaya dan macamnya ini divalidasi oleh ahli media guna menilai aspek kelayakan kegrafikan dan aspek kelayakan penyajian.

Tabel 4. Hasil Rekapitulasi Ahli Media

\begin{tabular}{ccccc}
\hline Aspek & $\begin{array}{c}\text { Nomer } \\
\text { Kuesioner }\end{array}$ & $\begin{array}{c}\text { Skor } \\
\text { Maksimum }\end{array}$ & $\begin{array}{c}\text { Skor } \\
\text { Perolehan }\end{array}$ & Presentase \\
\hline Kelayakan Kegrafikan & $37-44$ & 40 & 34 & $85 \%$ \\
\hline Kelayakan Penyajian & $13-15$ & 15 & 14 & $93 \%$ \\
\hline Total & 11 & 55 & 48 & $87 \%$ \\
\hline
\end{tabular}

Berdasarkan hasil diatas, validasi e-student worksheets berbasis literasi sains dalam pembelajaran IPA muatan gaya dan macamnya yang telah dinilai oleh ahli media dilihat dari aspek 
kegrafikan diperoleh presentase sebesar $85 \%$ dan aspek penyajian sebesar $93 \%$ sehingga didapatkan rata-rata kelayakan produk sebanyak $87 \%$ termasuk kategori sangat baik.Dibawah ini rekapitulasi expert review:

Tabel 5. Hasil Rekapitulasi Expert Review

\begin{tabular}{cc}
\hline Expert Review & Persentase. \\
\hline Ahli Materi & $96 \%$ \\
\hline Ahli Bahasa & $94 \%$ \\
\hline Ahli Media & $87 \%$ \\
\hline Total & $92 \%$ \\
\hline
\end{tabular}

Menurut tabel diatas, penilaiane-student worksheets berbasis literasi sains gaya danmacamnya yang laksanakanpakar expert review mencapai rata-rata kelayakan produk sebanyak $92 \%$ dan dikategorikan sangat baik.

Fase selanjutnya peneliti melaksanakan uji coba respon penggunaoleh peserta didik kelas IVdi SDN Lenteng Agung 03 dan guru SD di SDN LA 03. Dalam penilaian kelayakan produk lembar kerja elektronik pada respon pengguna oleh peserta didik dan guru berbeda dari prospek penilaian expert review. Adapun dalam penilaian respon pengguna berdasarkan beberapa prospek yaitu, kelayakan isi atau materi, motivasi, penyajian, kebahasaan, kemenarikan dan komponen literasi sains.

\section{Hasil Validitas Respon Pengguna oleh Peserta Didik dan Guru}

\section{a. Uji Coba One to One}

Uji coba one to onemerupakanfase permulaandilaksanakan peserta didik. Data diperoleh dengan wawancara dan menyebar kuesioner untuk melakukan penilaian terhadap e-student worksheetsberbasis literasi sains materi gaya dan macamnya setelah pengajaran dilakukan. Uji coba lapangan awal dilakukan di SDN Lenteng Agung 03. Narasumber dalam evaluasi ini terdiri dari 3 (tiga) orang peserta didik kelas IVB yang ditunjukmengikutigrade akademis yang pintar, kurang pintar dan tidak pintar. Tiga pepserta didik tersebut dipilih langsung oleh wali kelas IVB yang mengikut secara pasti tingkatan kemampuan akademik peserta didik di kelas IV. Adapun dalam pelaksanannya menggunakan zoom meeting.

Berdasarkan hasil wawancara dengan peserta didik, e-student worksheets berbasis literasi sains memudahkan peserta didik memahami materi, membangkitkan minat peserta didik untuk mempelajari materi gaya dan macamnya karena e-student worksheets berbasis Literasi menarik dan mudah untuk digunakan. E-student worksheetspun mudah uncuk dibaca dimana huruf dan penulisan jelas dan tajam dalam e-student worksheets.

Pada saat uji coba one to one di SDN Lenteng Agung 03 Jakarta Selatan, tiga orang peserta didik yang memberikan penilaian terhadap e-student worksheets berbasis literasi sains, rata- rata nilai yang diperoleh adalah $93 \%$. Hasil uji one to one evaluation terhadap e-student worksheets berbasis literasi sains dalam muatan IPA kelas IV Sekolah Dasar adalah sangat baik, yaitu dengan rata-rata presentase $93 \%$.

Tabel 6. Hasil Uji Coba One to One Evaluation

\begin{tabular}{ccc}
\hline No & Nama Peserta Didik & Penilaian Produk \\
\hline 1. & $\mathrm{MZ}$ & $94 \%$ \\
\hline 2. & $\mathrm{K}$ & $91 \%$ \\
\hline 3. & $\mathrm{MN}$ & $94 \%$ \\
\hline & Rata-rata Presentase & $93 \%$ \\
\hline
\end{tabular}




\section{b. Uji Coba (Small Group)}

Dalam tahap ini menyertakan 8 (delapan) peserta didik kelas IVB SDN Lenteng Agung 03yang dipilih oleh wali kelas IVB dimana peserta didik yang dipilih berbeda dari narasumber pada tahap one to one. Adapun dalam pelaksanannya menggunakan zoom meeting.Pada tahap ini responden juga menilai e-student worksheets berbasis literasi sains dengan aspek yang sama seperti tahap uji coba one to one..Jumlah butir soal dalam kuesioner sebanyak 27 butir pernyataan. Dibawah ini penyelidikan data uji coba small group.

Tabel.7. Hasil.Analisis Data Reakpitulasi Uji Coba Small Group

\begin{tabular}{ccc}
\hline No & Nama Peserta Didik & Jumlah Nilai \\
\hline 1. & PN & $81 \%$ \\
\hline 2. & AK & $94 \%$ \\
\hline 3. & CA & $91 \%$ \\
\hline 4. & MGM & $73 \%$ \\
\hline 5. & MFA & $90 \%$ \\
\hline 6. & MHPP & $84 \%$ \\
\hline 7. & IN & $76 \%$ \\
\hline 8. & VPJ & $100 \%$ \\
\hline
\end{tabular}

Berdasarkan tabel diatas, e-student worksheets berbasis literasi sains yang dilakukan oleh 8 (delapan) narasumber kelas IV SDN Lenteng Agung 03 diperoleh persentase sebanyak 86\% dan dikategorikan sangat baik.

\section{c. Uji Coba Pelaksanaan Lapangan (Field Test)}

Fase berikutnyayaitu diujicobakan untukanggotadalam jumlah besar peserta didik. kuantitas peserta didik pada uji pelaksanaan lapangan..(field test)yaitu 29 (dua puluh Sembilan) peserta didik kelas IVA SDN Lenteng Agung 03 Jakarta Selatan. Uji pelaksanaan lapangan ini dilaksanakan dengan memublikasikan e-LKPD, prosedurpenggunaan e-LKPD juga menerapkan praktikkumnan ada di e-student worksheetsketika aktivitas belajar IPA di kelas. Kuantitas pernyataan kuesioner sejumlah27 pernyataan dengan memanfaatkanrating scale dengan skala skor 1-5. Dibawah ini hasil penyelidikan data rekapitulasi uji pelaksanaan lapangan field test.

Tabel 8 Hasil Analisis Data Rekapitulasi Uji Pelaksanaan LapanganField test

\begin{tabular}{ccc}
\hline No & Nama Peserta Didik & Persentase \\
\hline 1. & AD & $92 \%$ \\
\hline 2. & S & $100 \%$ \\
\hline 3. & HA & $75 \%$ \\
\hline 4. & AR & $67 \%$ \\
\hline 5. & AR & $97 \%$ \\
\hline 6. & QL & $100 \%$ \\
\hline 7. & AW & $62 \%$ \\
\hline 8. & $\mathrm{~N}$ & $99 \%$ \\
\hline 9. & $\mathrm{RA}$ & $80 \%$ \\
\hline 10. & $\mathrm{RT}$ & $99 \%$ \\
\hline 11. & $\mathrm{CR}$ & $74 \%$ \\
\hline 12. & $\mathrm{MW}$ & $96 \%$ \\
\hline 13. & $\mathrm{~V}$ & $96 \%$ \\
\hline
\end{tabular}


Efektor, Volume 8 Issue 2, 2021, Pages 98-109

Anisa Asnawati, Sutrisno, Imaningtyas

\begin{tabular}{lcc}
\hline 14. & AR & $95 \%$ \\
\hline 15 & $\mathrm{FA}$ & $100 \%$ \\
\hline 16. & $\mathrm{MA}$ & $87 \%$ \\
\hline 17. & $\mathrm{ML}$ & $86 \%$ \\
\hline 18. & $\mathrm{~L}$ & $78 \%$ \\
\hline 19. & $\mathrm{NZ}$ & $60 \%$ \\
\hline 20. & $\mathrm{TA}$ & $80 \%$ \\
\hline 21. & $\mathrm{AN}$ & $100 \%$ \\
\hline 22. & $\mathrm{Al}$ & $80 \%$ \\
\hline 23. & $\mathrm{MF}$ & $74 \%$ \\
\hline 24. & $\mathrm{AS}$ & $82 \%$ \\
\hline 25. & $\mathrm{AT}$ & $77 \%$ \\
\hline 26. & $\mathrm{SA}$ & $82 \%$ \\
\hline 27. & $\mathrm{KR}$ & $94 \%$ \\
\hline 28. & $\mathrm{TK}$ & $73 \%$ \\
\hline 29. & $\mathrm{EO}$ & $76 \%$ \\
\hline & Jumlah & $84 \%$ \\
\hline
\end{tabular}

Berdasarkan tabel diatas, e-LKPD berbasis literasi sains yang menyertakan 29 orang peserta didik kelas IVA SDN Lenteng Agung 03 Jakarta Selatan didapatkan rata-rata sebesar $84 \%$ dan dikategorikan sangat baik.

\section{d. Penilaian oleh Guru}

Penggunaan oleh respon pengguna tak hanya dinilai oleh peserta didik saja guru sebagai pemakai pun memberikan nilai. Adapun penilaian berjumlah 27 butir dengan aspek yang terdiri prospek kelayakan atau materi, prospek penyajian, prospek kebahasaan, dan prospek komponen literasi sains. Validasi menggunakan rating scale dengan skor skala 1-5. Penilaian dilakukan oleh wali kelas IVA dan IVB, diperoleh hasil rekapitulasi sebagai berikut

Tabel 9. Hasil Rekapitulasi Penilaian Respon Guru

\begin{tabular}{|c|c|c|}
\hline No & Nama Guru & Persentase \\
\hline 1. & $\mathrm{HP}$ & $98 \%$ \\
\hline 2. & HM & $97 \%$ \\
\hline \multicolumn{2}{|c|}{ Jumlah } & $97 \%$ \\
\hline
\end{tabular}

Hasil uji respon pengguna oleh guru terhadap e-LKPD berbasis literasi sains yang dilakukan oleh wali kelas IVA dan wali kelas IVB SDN Lenteng Agung 03 Jakarta Selatan didapatkan ratarata sebesar $97 \%$ dan dikategorikan sangat baik.

\section{SIMPULAN}

Penelitian pengembangan e-student worksheets ini menghasilkan sebuah produk dengan nama "E-LKPD Berbasis Literasi Sains Materi Gaya dan Macamanya". Pengembangan produk e-student worksheets Berbassis Literasi Sains merujuk model ADDIE yang mencakup beberapa fase, yakni: analisis, desain, pengembangan, implementasi dan evaluasi.Pengembangan e-student worksheets Berbasis Literasi Sains ditinjau berdasarkanprospekkelayakan materi, penyajian, kebahasaan, kegrafikan, serta prospek komponen literasi sains. E-student worksheets Berbasis Literasi Sains berdasarkan penilaian expert review oleh pakar materi, bahasa, serta media. Penilaian ahli materi kelayakan pabrikasi $96 \%$, ahli bahasa kelayakan pabrikasi $94 \%$ serta ahli media dengan kelayakan pabrikasi $87 \%$. Segenap validasitergolongsangat baik.Fase selanjutnya e-student worksheets Berbasis 


\section{Efektor, Volume 8 Issue 2, 2021, Pages 98-109}

Anisa Asnawati, Sutrisno, Imaningtyas

Literasi Sains Materi Gaya dan Macamnya dinilai oleh 3 responden (uji coba one to one) dengan kelayakan 93\%. Selanjutnya e-student worksheets Berbasis Literasi Sains Materi Gaya dan Macamnya diujicobakan kepada 8 responden (uji coba small group) dengan kelayakan produk $86 \%$. Kemudian estudent worksheets Berbasis Literasi Sains diujicobakan pelaksanaan lapangan (field test) dengan kelayakan produk $84 \%$. Penilaian dalam responden termasuk kategori sangat baik.Penilaian respon pengguna tak hanya dinilai oleh peserta didik. Guru juga menilai sebagai respon pengguna. Adapun penilaian respon pengguna dilakukan oleh 2 (dua) orang responden yaitu wali kelas IVA dan wali kelas IVB dengan persentase rata-rata diperoleh dengan kelayakan produk sebesar $97 \%$. Penilaian dalam responden termasuk kategori sangat baik.

\section{DAFTAR RUJUKAN}

Kasina dan Lestari. 2010. Pengembangan Bahan Ajar Perkembangan Anak Usia SD Sebagai Sarana Belajar Mandiri. 2010. Jurnal Perspektif IImu Pendidikan, 22:183. <https://doi.org/10.21009/PIP.222.10>

Baharun, Hasan dkk. 2018. Model dan Desain Pembelajaran Inovatif, Kreatif dan Berkarakter. Probolinggo: Duta Media Publishing.

Branch, Robert Maribe. 2009. Instructional Design: The ADDIE Approach New York: Springer. http://dx.doi.org/10.31949/be.v2i1.589

Ermaniatu, N dan M. Taufik. 2017. Pengembangan Bahan Ajar Cetak Berbasis Penilaian Kinerja Sebagai Sumber Belajar Bagi Siswa SD Kelas IV. Jurnal Ermaniatu. N, M. Taufik, Pengembangan, 7 (3):285 <https://doi.org/10.24114/sejpgsd.v7i3.9251>

Hanafi. 2017. Konsep Penelitian R\&D Dalam Bidang Pendidikan. Jurnal Santifika Islamica: Jurnal $\begin{array}{lcr}\text { Kajian Keislaman, } & 4 & (2):\end{array}$

<http://jurnal.uinbanten.ac.id/index.php/saintifikaislamica/article/view/12 04>

Harusty, dkk. 2013. Pembelajaran Berbasis Literasi Sains Pada Materi Larutan Elektrolit dan Non Elektrolit di SMA Negeri 1 Pontianak. Jurnal Pendidikan dan Pembelajaran Khatulistiwa. 2 (2):2. $<$ https://jurnal.untan.ac.id/index.php/jpdpb/article/view/4002>

Juwita Tita, Nur Imiyati dan Adi Maladona. 2017. Analisis Kelayakan Buku Teks Siswa IPA Kurikulum 2013 Pada Materi Sistem Pencernaan Kelas VIII Untuk Digunakan Dalam Proses Pembelajaran Ditinjau Dari Relevansi Isi, Ketepatan dan Kompleksitas. Jurnal Bio Education, 2 (1): 64 $<$ https;//media.neliti.co./media/publications/279503-analisis-kelayakan-buku-teks-siswa-ipa-k$7 \mathrm{fd} 6 \mathrm{e} 616 . \mathrm{pdf}>$

Kristyowati, Reny. 2018. Lembar Kerja Peserta Didik (LKPD) IPA Sekolah Dasar Berorientasi Lingkungan. Prosiding Seminar dan Diskusi Nasional Pendidikan Dasar. UNJ, 284 UNJ ISSN:2528-5564<http://journal.uni.ac.id/unj/index.php/psdp/article/view/10150/6577>

Laksana, Dek Ngurah Laba. 2016. Miskonsepsi Dalam Materi IPA Sekolah Dasar. Jurnal Pendidikan Indonesia, 5 (2): 183. <http://dx.doi.org/10.23887/jpi-undiksha.v5i2:8588>

Nunuk Suryani, dkk. 2018. Media Pembelajaran Inovatif Pengembangangannya. Bandung: PT Remaja Rosdakarya.

Purnomo, Heru dan Insih Wilujeng. 2016. Pengembangan Bahan Ajar dan Instrumen Penilaian IPA Tema Indahnya Negeriku Penyempurnaan Buku Guru dan Buku Siswa Kurikulum 2013. Jurnal Prima Edukasia, 4 (1), 69, <https://doi.org/10.21831/jpe.v4i1.7697>

Puspita, Vivid an Ika Parma Dewi. 2021. Efektivitas e-LKPD Berbasis Pendekatan Investigasi terhadap Kemampuan Berfikir Kritis Siswa Sekolah Dasar. Dalam Jurnal Cendekia: Jurnal Pendidikan Matematika, 5, (!), 89<https://doi.org/10.31004/cendekia.v5i1.456>

Theresa Schulte. 2017. Desireble Science Education: Findings From a Curricular Delphi Study on Scientific Literacy in Germany: Germany: Springer Spekstrum. 
Windyariani, dkk. 2016. Pengembangan Bahan Ajar Berbasis Konteks dan Kreativitas untuk Melatihkan Literasi Sains Siswa Sekolah Dasar. Jurnal Bioedukatika, 4(2), 20. P-ISSN: 2338-6630 e- ISSN: 2541-5646. <http://journal.uad.ac.id/index.php/BIOEDUKATIKA/article.view/5326/3109>

Yuberti. 2014. Teori: Pembelajaran dan Pengembangan Bahan Ajar Dalam Pendidikan. Lampung: Anugrah Utama Raharja.

Zahroh, Dwi Aulia. 2021. The Development of Scientific Literacy Based e-LKPD to Train Student's Critical Thinking Skills In Growth and Development Materials. Jurnal Bio Edu, 10 (3), (615). <https://ejournal.unesa.ac.id/index.php/bioedu> 